\title{
Argeologie van homofobie: Boustene van mag
}

\begin{abstract}
Authors:
Mark le Roux ${ }^{1}$

Yolanda Dreyer ${ }^{1}$

\section{Affiliations:}

${ }^{1}$ Department of Practical

Theology, University of

Pretoria, South Africa

Note:

This article is based on the research of Mark le Roux's MTh dissertation, entitled 'Argeologie van homofobie'. The research was done under the supervision of Prof. Dr Yolanda Dreyer, Department of Practical Theology, Faculty of Theology, University of Pretoria (2013).
\end{abstract}

\section{Correspondence to:}

Yolanda Dreyer

Email:

yolanda.dreyer@up.ac.za

Postal address:

Private Bag X20, Hatfield

0028, Pretoria, South Africa

\section{Dates:}

Received: 31 July 2013

Accepted: 01 Aug. 2013

Published: 04 Nov. 2013

How to cite this article: Le Roux, M. \& Dreyer, Y., 2013, 'Argeologie van homofobie: Boustene van mag', HTS Teologiese Studies/Theological Studies 69(1), Art. \#2042, 8 pages. http://dx.doi.org/10.4102/ hts.v69i1.2042

\section{Copyright:}

(C) 2013. The Authors. Licensee: AOSIS OpenJournals. This work is licensed under the Creative Commons Attribution License.

\section{Read online:}

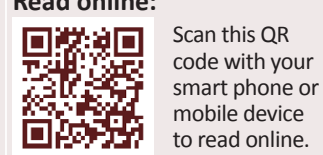

Archaeology of homophobia: Building blocks of power. The article investigates presentday discourses which demonstrate coercive power with regard to sexuality according to which people are attributed an identity. Such hegemony restricts existential authenticity. The article shows that, although sexual minorities could have public rights according to constitutional law, they still experience marginalisation because of victimisation on account of a heteronormative societal discourse. The article consists of an introductory section in which Michel Foucault's notion of 'the archaeology of knowledge' is used to explore levels of perceptions in society which illustrate perceptions and ideas on homophobia. The first section focuses on the phenomenon of stigmatisation. The second section describes the process of stereotyping taboos that result in the phenomenon of internalised homophobia. The article concludes with a deconstruction of homophobia by emphasising the recognition of the Other by means of a contradiscourse to heteronormativity.

\section{Isitabane - Die probleem van stigmatisering}

Die argeologie van diskoerse in die samelewing ten opsigte van homofobie word in hierdie artikel ondersoek met behulp van die metodologie wat Michel Foucault (1972) gebruik het in sy werk, The archaeology of knowledge. Dit is 'n ondersoek na die strata van persepsies en idees oor homofobie, 'n verskynsel wat aangetref word in 'n heteronormatiewe samelewing. Soos wat ontdekkings in argeologiese opgrawings insigte verleen ten opsigte van sekere kultuurgebruike in 'n spesifieke tyd, so kan 'n ondersoek na die diskoerse ten opsigte van homoseksualiteit en die fenomeen van homofobie lig werp op die ontwikkelingsprosesse wat gelei het, en steeds lei, tot die meesternarratiewe in die samelewing en kerk.

Suid-Afrika het een van die mees progressiewe grondwette wat die regte van seksuele minderhede beskerm, 'n grondwet wat ontstaan het uit die ideale van die post-apartheidsera en in die gees van ubuntu, ${ }^{1}$ met menslike waardigheid, gelykheid en vrede as grondslag (Van Niekerk \& Wildeboer 2009:173). Ten spyte van 'n hoë mate van grondwetlike beskerming word homoseksuele persone egter steeds na die rand van sosiale en godsdienstige kringe, asook die werkplek uitgeskuif. Sommige skole en kerkgroepe propageer dat homoseksuele mense van hulle homoseksualiteit 'genees' kan word (vir hierdie tendens, kyk bv. News24 13 Januarie 2013). Homoseksuele persone is soms die teiken van geweldpleging en gevalle van 'regstellende verkragting'. Die doel van die geweld is om hulle tot normatiewe seksualiteit te dwing (Wells \& Polders 2006:20-22).

Die sosiale verskynsel van homofobie kan toegeskryf word aan 'n verskeidenheid faktore, wat wissel van fundamentalistiese geloofsopvattings tot algemene wanopvattings oor homoseksualiteit. 'n Psigologiese oorsaak is dat sommige mense ongemak ervaar wanneer hulle meen dat tradisionele geslagsrolle in gedrang kom. In Swart of Afrika-kulture word homoseksualiteit dikwels beskou as die gevolg van Westerse invloede, wat derhalwe uit die weg geruim moet word (Reddy 2001: 163-170). Soms word homoseksualiteit in hierdie samelewings gekriminaliseer. In Suid-Afrika word die neerhalende Zuluwoord isitabane gebruik om na homoseksuele persone te verwys. Dit is soortgelyk aan woorde soos 'moffie' of 'sissie' (Reddy 2001:168). In die Nuwe Testament gebruik Paulus die woord, malakos, om na 'n verwyfde swakkeling van 'n man te verwys (1 Kor 6:9; kyk Martin [1996] 2013).

Die Suid-Afrikaanse samelewing bestaan uit kulture wat sterk tradisioneel en patriargaal funksioneer, met eng gedefinieerde geslagsrolle. In gesinne waar hierdie geslagsrolle gehandhaaf word, word vroue byvoorbeeld gesien as ondergeskik aan die man. Die man word as die hoof van die gesin en die broodwinner beskou. Sy manlikheid is onweerlegbaar. Dit is juis in sulke samelewings dat homofobiese sentimente gedy en dat min of geen ruimte vir homoseksuele individue gemaak word nie.

1. 'Ubuntu has been translated as a feeling of common humanity, a spirit of humaneness, social justice and fairness. It refers to the art of being a human being and includes a number of virtues such as tolerance, compassion and forgiveness in relation to other human beings. Ubuntu has also been called African humanism' (Van Niekerk \& Wildeboer 2009:177). 
'Homofobie' is verwant aan verskynsels soos rassisme en seksisme (vgl. Brown 2008; Davidson 1987; Dias et al. 2001). Die term 'homofobie' is die eerste keer in 1967 deur die sielkundige George Weinberg gebruik. Dit dui op 'n vrees vir mense met 'n homoseksuele oriëntasie. Die term druk iets uit van 'n weersin in homoseksuele persone, hoewel dit nie werklik gaan om 'n fobie of vrees nie, maar, soos in die geval van rassisme en seksisme, oor vooroordeel. Dit verskuif die fokus van die homoseksuele individu na die reaksie van ander op homoseksualiteit (Herek 2004:6-14) en versag daardie reaksie met behulp van 'n eufemisme: 'vrees', in plaas van 'vooroordeel'.

Die vooroordeel waarmee homoseksuele mense in die samelewing behandel is, het 'n platform vir die latere gayvryheidsbeweging geskep. $\mathrm{Al}$ is goeie vordering reeds gemaak ten opsigte van gelyke regte vir alle mense, is daar steeds wanpersepsies oor die gedrag van homoseksuele persone. Dít, en die handhawing van tradisionele geslagsrolle, veroorsaak steeds spanning tussen die hetero-norm wat in die samelewing geld en die werklikheid van homoseksuele persone. Ook in Suid-Afrika kom haatspraak en selfs haatmisdade teenoor homoseksuele persone en gay-vriendelike mense en instansies voor. 'n Geval wat heelwat mediablootstelling gekry het, was die bomaanval op 'n gay-kuierplek, die Blah Bar in Kaapstad, in die vroeë oggendure van Saterdag, 06 November 1999 (BBC News 06 November 1999). Meer onlangs is berig dat 'n voormalige Miss Gay Kuruman-wenner, Thapelo Makutle, na 'n onderonsie met twee mans oor sy seksualiteit onthoof is (News24 13 June 2012). Die plaaslike vermaaklikheids- en sportwêreld swyg oor bekendes se homoseksualiteit uit vrees dat dit hulle loopbane en gewildheid nadelig sal beïnvloed. Homoseksuele kinders wat afgeknou word by skole, is 'n algemene verskynsel. Hierdie soort gedrag kom steeds voor, selfs nadat die nuwe menseregtehandves aanvaar is.

Homofobie manifesteer met wisselende intensiteit op verskeie vlakke in die samelewing en het verreikende gevolge. Hierdie artikel wil daartoe bydra om onreg te onbloot en 'n bewuswording te skep wat tot groter geregtigheid vir homoseksuele mense kan lei. 'n Bewustheid van onreg kan tot veranderde denke oor homoseksualiteit en die bekamping van haatmisdade bydra.

In Suid-Afrika is die staat, en nie die kerk nie, meesal die voorloper as dit kom by die bevordering van die regte van minderheidsgroepe. Die kerk versuim dikwels om 'n profetiese stem teen onreg en onderdrukking te laat hoor. Anders as die Afrikaanstalige kerke, was Engelstalige kerke wel bereid om hulle uit te spreek teen rassisme (Nieman 2010:n.p.). Albei groepe is egter steeds onwillig om gay mense onvoorwaardelik te aanvaar. Die onwilligheid van kerke om uitsprake teen die sosiale norm te maak het grootliks te make met die vooroordele van lidmate op grondvlak. Die vooroordeel teen homoseksualiteit hou ten nouste verband met die verstaan van geslagsrolle (Raja \& Stokes 1998:113-134).

Hierdie artikel het ten doel om die verskynsel 'homofobie' te ondersoek en 'n bydrae tot die hedendaagse gay-diskoers en die bevordering van gay-regte te lewer. Die hooffokus is op die gelaagdheid van homofobie, hoe hierdie kompleksiteit in homofobiese diskoerse geartikuleer word en hoe dit in onder andere geslagsrolle manifesteer.

\section{Mag en die 'ander' Die rol van mag}

Die werk van Herek $(2004,2007)$ bied vir hierdie artikel 'n raamwerk en die terminologie om die gelaagdheid van homofobie te bespreek. Die werk van Constantine-Simms (2001), The greatest taboo: Homosexuality in black communities word benut om insigte in die ervarings van homoseksuele persone in Swart gemeenskappe te verkry. 'n Suid-Afrikaanse studie deur Otto (2003) bied 'n raamwerk vir die ondersoek na die ervaring van homoseksuele persone. Die doel is om diskoerse ten opsigte van homofobie in die narratiewe van mense wat deur homofobie geaffekteer word, te identifiseer. Die werk van die filosoof Michel Foucault (1978, [1982] 2001a, 1997) bied insig in aspekte soos die konstruksie van mag, diskoers-analise en sosiale beheermeganismes. Foucault ([1969] 1982) se insig dat sosiale onderdrukking bewerkstellig word deur middel van 'ekspert'-kennis om 'n sosio-politieke ideaal te bevorder ten koste van ander, is ter sake. Halperin (1995) pas Foucault se werk spesifiek toe op die homofobiediskoers en Otto (2003) pas Levinas en Poller (2003) se insigte ten opsigte van die 'Ander' toe op die verskynsel homofobie.

\section{Die vloeibaarheid van mag}

Dat mag ten opsigte van seksualiteit uitgeoefen is met behulp van politieke en sosiale beheermeganismes, is deur Foucault (1980:125) uitgewys. Hy verwys daarna as 'bio-power'. Individue word op 'n spesifieke manier geklassifiseer sodat die samelewing sy doelwitte kan bereik. Om mag te behou is die hoofmotivering vir hoe die 'waarheid' gekonstrueer word (Otto 2003:28; vgl. McHoul \& Grace 1993:57). Foucault (1972:4, 1980:109-133) onderskei drie soorte kategorisering, naamlik stereotipering, etikettering en die klassifikasie van mense deur middel van binêre opposisies soos 'geestesgesond' teenoor 'geestesversteurd'. Dit kom neer op 'n redusering van mense. Sulke sosiaal-gekonstrueerde 'waarhede' word geïnternaliseer en deur 'self-polisiëring' onderhou. Die konsep 'panopticon' kan lig hierop werp.

In 1791 het die Engelse filosoof Jeremy Bentham (kyk Miller \& Miller 1987:3) in sy uiteensetting van die ideale ontwerp van 'n tronk die term 'panopticon' gebruik. Die doel van die toring in die middel van 'n sirkelvormige tronk is dat min tronkbewaarders oor baie gevangenes beheer kan uitoefen. Die selle is so gestruktureer dat daar geen privaatheid kan wees nie. Persone in die selle weet nooit of hulle op daardie spesifieke oomblik dopgehou word nie, omdat hulle nie self die toring kan sien nie. Die gevangenes voel konstant dat hulle dopgehou word (Van Aarde 2012:3). Dit noodsaak die gevangenes tot self-regulering of self-polisiëring as gevolg van die konstante opsig (Bevir 1999:66).

Panopticon kan as metafoor gebruik word vir hoe persone hulleself etiketteer en aan die sosiale konstrukte onderwerp 
wat vir hulle geskep word. 'n Voorbeeld hiervan is dat homoseksuele pare nie maklik tussen ander mense in ' $n$ openbare plek soos 'n winkelsentrum sal hande vashou nie. Hulle doen dit om nie aanstoot te gee of ander ongemaklik te maak nie. Daarteenoor laat heteroseksuele persone hulle nie so inhibeer nie. Homoseksuele persone reguleer en beperk hulleself om aan te pas by die dominante heteronormatiewe diskoerse.

Foucault ([1982] 2001b:326-348) meen dat 'n nuwe vorm van mag ontstaan het: individuele persone in hulle eie unieke omstandighede konstrueer ' $n$ identiteit en verbind hulleself tot sekere waarhede. Hierdie identiteitskonstruksies beperk die mens tot die etiket, veral as die etiket te doen het met 'n afwyking van die norm. 'n Uitspraak wat mense beperk, is byvoorbeeld dat homoseksuele pare nooit 'n vervullende emosionele verhouding sal kan hê nie omdat hulle verbintenis nie biologiese voortplanting tot gevolg kan hê nie (kyk Foucault 1985:10-11; Richlin 1997:138-170). Wie voorskryf wat die normatiewe waarheid sal wees en die ander stereotipeer, kry mag oor die ander (kyk Otto 2003:28).

Sulke uitsluitende normatiewe 'waarhede' (vgl. Foucault 1972:4, 1980:109-133, 1997:171-198, [1982] 2001a:111-133, [1982] 2001b:326-348) het oor die eeue heen ten opsigte van seksualiteit gefunksioneer. Die kerk in die Middeleeue het seksualiteit moralisties verstaan en homoseksualiteit op grond daarvan afgekeur. Tydens die negetiende en in die vroeg twintigste eeu het die dominante diskoers die 'waarheid' oor homoseksualiteit as 'aangeleerde afwyking' gedefinieer.

Die verskillende vorme van mag het vir Foucault ([1982] 2001b:334), veral in die moderne tyd, 'n 'matriks van individualisering' geword wat normalisering gebruik om beheer uit te oefen. Omdat die matriks deur 'n netwerk van faktore gevorm word, is dit moeilik om die faktore te eien. Wat homofobie moeilik maak om te identifiseer en ondersoek, is die sosiale verweefdheid van die faktore en aspekte waaruit dit bestaan. Die bevrydingsbewegings in die laat twintigste eeu wat gevolg het op die spoor van die feministiese beweging, het ten doel gehad om geïnstitusionaliseerde anti-gay houdings te dekonstrueer en gelyke regte vir homoseksuele persone (ten minste in die regstelsel) bewerkstellig. Gay-regte verskil van land tot land. Die houding van die mense, selfs in lande wat gay-regte beskerm, strook nie altyd met die gees van die wetgewing nie.

Die pastorale vraag is hoe individue uit die onderdrukking van mag sou kon uitbreek en hoe mense wat in 'n sosiale konteks van stigmatisering vasgevang is (die slagoffers van stereotipering en etikettering), hulleself daaruit sou kon bevry. In sy bespreking oor die verset teen mag onderskei Van Aarde (2012) twee werkwyses: eerstens 'n kritiese sosiaal-wetenskaplike ondersoek na die 'meesternarratief' ('n teoretiese fokus) en tweedens 'n sosiaal-kritiese ondersoek wat daarop fokus om individue uit hulle konteks van die mag te bevry ('n emansipatoriese fokus). Teorie en bevryding op grondvlak behoort in kombinasie aangewend te word. Daarom wil hierdie artikel nie net 'n bydrae lewer tot die dekonstruksie van samelewingsdiskoerse wat homoseksuele persone met homofobiese houdings en stereotipering verlam nie, maar ook homoseksuele persone bemagtig om op grondvlak binne hulle eie unieke omstandighede teen die verlammende diskoerse weerstand te bied.

Mag is nie die besitreg van 'n klein elite groep of instansie is nie, maar is dinamies (Halperin 1995:17). Dit manifesteer in die komplekse relasionele verhoudings in 'n samelewing. Mag word nie besit nie, maar word uitgeoefen. Hoewel mag ongelyk verdeel word, is dit vloeibaar en teenwoordig op alle vlakke van die samelewing. Mag hoef nie net as negatief gesien te word nie, maar kan ook 'n positiewe, skeppende krag wees wat geleenthede oopmaak. Die positiewe gebruik van mag skep die moontlikheid tot vryheid. Hierdie vryheid is nie losstaande van mag nie, maar word juis deur mag moontlik gemaak (Halperin 1995:17). Op hierdie manier word vryheid nie meer in 'n binêre opposisie teenoor mag vasgevang nie, maar is intrinsiek daaraan gekoppel (Otto 2003:29). Mag hoef nie afgebreek te word om dit te oorwin nie, dit is vrylik beskikbaar en kan wedersyds en konstruktief aangewend word. Halperin (1995:32) meen dat diskoerse in die samelewing wat van homofobie getuig, deur konstante weerstand afgebreek kan word. Sosiaal-kritiese benaderings het nie ten doel om magskontruksies (wat op sekere waarhede gebaseer word) af te breek nie, maar eerder om die waarheidsbasis van dominante diskoerse deur middel van weerstand te verskuif. Wanneer die persoon wat weerstand bied, ' $n$ ander houding tot die konteks inneem en as 't ware 'n nuwe identiteit vorm, sal die magsrelasie verander. So kan die voorheen benadeelde persoon bemagtig word. Indien bemagtigde persone die nuwe identiteit konstruktief en verantwoordelik in die samelewing gebruik om verandering te weeg te bring, kan die openbare mening verander en vooroordele teenoor homoseksualiteit en homoseksuele mense oorstyg word. So 'n nuwe outentieke identiteit kan vir homoseksuele persone groter selfvertroue en vrede meebring, selfs in die konteks waarin hulle leef. Volgehoue weerstand verg ' $n$ sterk emosionele onderbou en stamina. Die ondersteuning en liefde van vriende en familie speel 'n bepalende rol in die bevryding en psigies gesonde lewe van homoseksuele mense.

\section{Waarheid as 'n konteks-bepaalde veranderlike}

Om die individu sterk te maak om 'n onderdrukkende bestel te bestry is maar een aspek van Foucault se sistematiese proses van dekonstruksie. Diskoerse self behoort ook ondersoek te word in terme van die effek wat hulle het (Halperin 1995:31), naamlik om mense te reduseer (McHoul \& Grace 1993:31). Diskoerse wat deur sisteme van kennis geskep word, bepaal die lewensruimte en bestaansreg van 'n individu. As daardie ruimte beperk of 'n persoon se bestaansreg ontken word, is dit vernietigend vir die persoon. Die doel is daarom om die sogenaamde 'waarhede' te transformeer (Halperin 1995). Die volgende insigte is van belang vir die transformasie van die 'waarhede': 


\section{Waarheid as'n konteks-bepaalde veranderlike}

In die premoderne wêreld is kennis deur waarneming bekom. Dit het tot 'n reduksionistiese verstaan van waarheid gelei. Die essensialistiese verstaan van seksualiteit is ' $n$ voorbeeld daarvan (vgl. McHoul en Grace 1993).

In die moderne wetenskap gaan dit om sisteme van kennis wat geproduseer word (McHoul \& Grace 1993:33; vgl. Spargo 1999:14). Volgens Spargo (1999:15) word magsdiskoerse op sogenaamde 'waarhede' gebou en in taal geartikuleer wat die magskonstruksies versterk. Kennis wat op geproduseerde waarheid berus, is veranderlik (Foucault [1982] 2001a; McHoul \& Grace 1993:58). Sisteme van sosiaal-gekonstrueerde kennis waarin magsbelange teenwoordig is, reguleer sosiale aktiwiteite. Kennis wat op geproduseerde waarheid berus (en as boustene vir diskoerse dien), is verweef met die konteks waarin dit geskep word. Vir Foucault ([1982] 2001a) is kennis dus 'n produk van die sosiale, historiese en politieke omstandighede waarin dit as waar of onwaar beoordeel word (vgl. McHoul \& Grace 1993:29). Wanneer die produksie van kennis binne 'n spesifieke konteks ondersoek word, verdien die magsdinamiek besondere aandag. Die gekonstrueerde 'waarheid' kan gebruik word om individuele optrede te reguleer (kyk McHoul \& Grace 1993:58). Waarheid wat in 'n sosiale konteks as onweerlegbare absolute kennis beskou word, word gekanoniseer.

Die 'waarheid' oor homoseksualiteit en seksualiteit is geproduseerde kennis. Daar is geen a-historiese waarheid oor seksualiteit nie. Homoseksualiteit is 'n verskynsel wat in alle kulture voorkom, maar verskillend geïnterpreteer en uitgeleef word. Hierdie benadering is 'anti-essensialisties en kultuur-konstruksionisties' (kyk Dreyer 2006b:163). Dominante diskoerse reguleer persone deur middel van die konstruksie van sosiale waardes en norme ten opsigte van seksualiteit.

\section{Diskoerse dien belange}

Foucault fokus nie soseer op die inhoud van die gekonstrueerde waarhede nie, maar eerder op die voordeel wat maghebbers daaruit trek (kyk Halperin 1995:31). Homoseksuele persone het byvoorbeeld minder toegang tot hulpbronne soos wetlike ondersteuning vir hulle verhoudings, asook werkgeleenthede. Hulle het minder invloed oor ander en het selfs minder beheer oor hulle eie leefwyse (Herek 2004:2). Hierdie beheer en deprivasie word meegebring deur die krag van diskoerse oor seksualiteit en homoseksualiteit in die samelewing en stigmatisering. Diskoerse, soos die sosiaal-gekonstrueerde waardes en norme (vgl. Allport 1958, kan gebruik word om bepaalde magsbelange in stand te hou. In antieke Mediterreense samelewings, spesifiek in die Grieks-Romeinse konteks, moes die manier waarop mense tydens die seksdaad optree, met hulle sosiale stand in die samelewing ooreenkom. Die een met hoër status mag nie die passiewe party gewees het nie. Mag is aan aktiewe manlike seksualiteit gekoppel (vgl. Dreyer 2005:740). Manlike magsbelange is gedien, beskerm en versterk. Passiewe manlike seksualiteit is beskou as 'n bedreiging omdat dit die 'waarhede' waarop die magskontruksies berus het, ondermyn het.
In die goue era van ekonomiese en politieke opbloei in die laat agtiende en die negentiende eeue is verskeie vorme van seksuele gedrag as 'perversiteit' geklassifiseer. Foucault (1978:36-37) vra watter magsbelang daardeur gedien is. In die Grieks-Romeinse kultuur het die diskoerse byvoorbeeld die mag van 'n manlike elite beskerm. Tydens die industriële era dien diskoerse om die ideologie van die kerngesin te beskerm en ekonomiese mag in die hande van die manlike elite te hou. Die vraag is watter magsbelange hedendaagse diskoerse oor seksualiteit dien.

Hedendaagse magsuitoefening oor seksualiteit neem die vorm aan dat vir mense 'n gereduseerde identiteit gekonstrueer word. So word hulle selfverstaan beperk (Foucault [1982] 2001b:331). Hoewel homoseksualiteit deesdae in die 'erkende' spektrum van seksualiteit ingesluit word, word homoseksuele individue steeds benadeel en gereduseer (kyk McWhorter 1999:13). Herek (2004) wys uit hoe 'toelaatbare' homoseks dikwels tot 'blote eksperimentering' gereduseer word. Sulke normaliseringspogings hou die idee van homoseksualiteit as ' $n$ abnormale fenomeen wat nie by die heteroseksuele norm pas nie, in stand. Daar word nie erkenning aan 'n eie homoseksuele identiteit gegee nie. Dit word steeds teen heteroseksualiteit afgespeel ten einde dit te kan normaliseer (Gurney 1999:168). Die hedendaagse proses van normalisering gebruik weereens die norm as maatstaf vir hoe mense móét leef, en hierdie norme word deel van die heersende diskoers oor seksualiteit. Daarmee word seksualiteit gereguleer.

Etikettering is ' $n$ magsinstrument wat steeds in hedendaagse diskoerse funksioneer. Identiteite wat so gekonstrueer word, dien die doel dat 'afwykings van die norm' duidelik uitgewys kan word. Foucault ([1982] 2001b:327) wys daarop dat individue hulle eie gedagtes en gedrag op grond van hierdie toegekende identiteite reguleer ten einde dit aan te pas by wat 'samelewingsnorme' vir hulle identiteit voorskryf (vgl. Bevir 1999:66). Om so te konformeer aan die gekonstrueerde identiteite, versterk nie net die diskoerse nie, maar maak ook van mense 'docile bodies' (kyk Van Aarde 2012:6). Die samelewing beloon dié wat konformeer en straf of benadeel dié wat dit nie doen nie (kyk Robinson \& Ferfolja 2002:61). 'n Voorbeeld hiervan is die twintigste-eeuse aversieterapie wat ten doel gehad het om homoseksuele persone se seksualiteit te verander (vgl. De Gruchy \& Lewin 2001:866; Otto 2003:70).

Die beloning-/strafmodel van normalisering word geillustreer in die besluit van die Algemene Sinode (2007) van die Nederduitse Gereformeerde (NG) Kerk, wat lui dat homoseksuele studente wel gelegitimeer kan word, maar slegs tot die bediening toegelaat sal word indien hulle selibaat bly (NGK 2007:205). Wanneer die betrokke persoon nie met die toegekende identiteit konformeer nie, sal hulle hulle roeping en die finansiële sekuriteit van 'n beroep ontneem word. Die toegekende identiteit sal nie die huidige bestel versteur nie en dien dus die belange van die dominante groep. Die teenwoordigheid/stem van andersheid word gereduseer en/ of stilgemaak. Andersheid word genormaliseer indien mense konformeer. Daarmee word die mense gereduseer, hulle lewensruimte beperk en hulle word die reg ontsê (wat lede 
van die dominante groep wel vir hulleself toeëien) om hulle identiteit self te definieer.

In die hedendaagse Suid-Afrikaanse samelewing is daar 'n verskeidenheid diskoerse wat die andersheid van die homoseksuele identiteit wil temper en/of beheer, ten spyte van die progressiewe menseregte waarop die land roem (kyk Farlam 1997:133; Otto 2003:81). Otto (2003:86) identifiseer sulke diskursiewe velde as: die psigiatrie, die psigologie, die onderwys, die weermag, asook wetgewing. Deur antigay-diskoerse in die samelewing word die heteroseksistiese ideaal bevorder, veral in militêre kringe en die onderwys (Herek 1992:89-104). Ten spyte van vordering wat op teoretiese vlak in Suid-Afrika gemaak is, het dit nog lank nie altyd deurgewerk van die praktyk en na die gemeenskap nie.

Vordering is egter wel gemaak. Die reg in Suid-Afrika bied beskerming teen diskriminasie (kyk byvoorbeeld die koerant, Beeld 2008, 2011a, 2011b). Mense kan hulle tot die regbank wend om gevalle van viktimisasie by die werkplek, onregmatige afdankings en naamskending te beredder. In die geval van haatmisdade kan selfs die regstelsel egter nie kompenseer vir die verlies aan eiewaarde en die gevolge van trauma en fisiese nie.

\section{'n Militante strategie}

Die noodsaak van weerstand is reeds beredeneer. Die vraag is nou hoe homoseksuele mense in die Suid-Afrikaanse konteks weerstand teen homofobiese diskoerse sou kon bied. Weerstand teen onderdrukking van homoseksuele identiteite is nie ' $n$ onlangse fenomeen nie. Gay-bevrydingsbewegings het sedert die 1950's stadig maar seker begin momentum kry. Die eerste openbare homofiele groep is in 1953 gevorm (Rizzo 2006:206). Hulle doel was om anti-gay-wette teen te staan en onkunde oor homoseksualiteit uit die weg te ruim (Rizzo 2006:206-212). In 1969 het 'n gay-protesoptog in New York begin ná 'n polisieklopjag op 'n gay-kuierplek. Soortgelyke optogte het in Australië, Brittanje, Italië, Duitsland en Frankryk gevolg, en mense het op sosiale hervorming aangedring (Rizzo 2006:216). Bewusmakingspogings het gefokus op die boodskap dat 'n homoseksuele oriëntasie ook natuurlik is en dat homoseksuele mense geregtig is om gelykwaardig met ander behandel te word, ook voor die wet. Die 1970's is gekenmerk deur groter aktivisme (kyk Tomsen 2001:8) wat saamgeval het met kennis oor die MI-virus. Dat homoseksualiteit as 'n geestesversteuring verwyder is uit die Diagnostic and Statistical Manual of Mental Disorders (DSM-III), was een van die direkte gevolge van die gaybevrydingsbeweging (kyk Silverstein 2008).

Foucault is egter krities teenoor die omgekeerde diskoers van gay-'vryheid' waar dieselfde 'patologiserende terminologie, kategorieë en konsepte' waarmee homoseksuele persone voorheen beskryf is, nou net deur gay-bevrydingsbeweging positief geartikuleer word (Foucault, in Halperin 1995:56-62). Hierdie terme, selfs wanneer dit positief gebruik word, versterk steeds die binêre opposisie van homoseksualiteit teenoor heteroseksualiteit. Die vordering konstitueer nog nie werklik 'bevryding' nie. Die doel van die gay-bevrydings- beweging is om vry te kom van gekonstrueerde identiteite. Dominante diskoerse sal verder gedekonstrueer moet word, weerstand sal verder gebied moet word sodat die skade aan mense sover moontlik geminimaliseer kan word.

Daar is reeds beredeneer dat die normalisering van andersheid met die doel om dit stelselmatig uit te skakel, die belange van die dominante groep dien. Dit is nie werklik vir seksuele minderhede tot voordeel nie, ook al kom dit 'vriendelik' voor. Die geskiedenis is deurtrek van voorbeelde van hoe minderheidsgroepe stilgebly het en stil gehou is deur dominante diskoerse en maghebbers van die dag. ' $n$ Voorbeeld is die maniere waarop homoseksualiteit tydens die apartheidtyd in Suid-Afrika onderdruk en gereguleer is (kyk De Gruchy \& Lewis 2001:866; Otto 2003:80). In die bevrydingstryd ten opsigte van ras, geslag en later ook homoseksualiteit, word die term 'voicelessness' gebruik om die vernietigde identiteit van mense wat in vyandige en onderdrukkende omstandighede leef, uit te druk (kyk Berman 1970:325). Om 'n mens se stem te herwin is om los te breek uit die stilte en 'n mens se regmatige plek in die samelewing in te neem. Om 'terug te praat' is om standpunt in te neem, om as 'n gelyke met gesag met die ander in gesprek te tree (kyk Hooks 1989:9). Meningsverskil bring nie die gesprek tot 'n einde nie. Inteendeel, dit maak dialoog moontlik. Juis in dialoog kan waarheid ontdek word.

Foucault se onderskeid tussen waarneembare waarheid en geproduseerde waarheid bied 'n lens vir die interpretasie van homoseksualiteit en die homofobie in die samelewing: waarneembare waarheid (essensialisme) het homoseksualiteit as 'onnatuurlik' benoem. Geproduseerde waarhede in die moderne tyd het homoseksuele persone tot 'wanaangepaste geestesversteurdes' verklaar. Die etikette van beide eras het tot stemloosheid gelei. Die kennis wat homoseksuele persone begin produseer het, is stadigaan besig om erken te word as 'a position from which one can know ... a legitimate condition of knowledge' (Halperin 1995:60; vgl. Spargo 1999:1-42). Hierdie nuwe platform skep die ruimte vir homoseksuele persone om die dominante diskoerse te weerstaan. Aanvanklik word met behulp van omgekeerde diskoerse oor homoseksualiteit gepraat. Dit is egter nie ideaal nie. Dit is nodig om verder te gaan as die winste van die bevrydingsbewegings.

\section{Bevinding}

In die twintiste eeu het homoseksuele mense begin weerstand bied deur middel van 'n kontradiskoers, 'n opinie wat reëlreg teen die normatiewe ingaan (Moussa \& Scapp 1996:93). Die doel was om ruimte vir stemloses te bied om self hulle behoeftes en identiteit te artikuleer. Foucault is egter krities oor omgekeerde diskoerse omdat dit die gekonstrueerde identiteite oor homoseksualiteit op 'n omgekeerde manier toe-eien. Homoseksuele mense bly steeds funksioneer binne die grense van die terminologie wat 'n heteroseksistiese samelewing geskep het. Al waarin die omgekeerde diskoers geslaag het, was om hierdie (gegewe) identiteit beter te laat voorkom. Die speelveld bly dieselfde. Hoewel nie ideaal nie, was hierdie oorgangstrategie nodig en is noemenswaardige vordering wel gemaak. 
Wat 'n kontradiskoers van 'n omgekeerde diskoers onderskei, is dat dit die speelveld verander. ' $n$ Kontradiskoers (anders as 'n omgekeerde diskoers) skep 'n unieke identiteit buite die beperkende definisies en binêre konstruksies wat deur die dominante diskoers geproduseer is. Dit maak dit moontlik om 'n eiesoortige identiteit te artikuleer. Daar is nie ' $n$ bestaande struktuur waarbinne homoseksuele verhoudings móét inpas nie. Wanneer homoseksuele persone hulleself definieer, doen hulle dit op 'n unieke wyse wat los staan van die verwagtings van die samelewing.

Deur kontradiskoerse bied hulle weerstand teen heteroseksistiese diskoerse. Met behulp van kontradiskoerse word eie unieke waarhede vanuit eie unieke omstandighede geproduseer. Die verhaal van die voormalige Walliese rugbykaptein, Gareth Thomas, kan hier as voorbeeld dien. Die 35-jarige Thomas het te midde van die oorheersend manlike (heteroseksuele) omgewing, nie net erken dat hy gay is nie, maar ook die stereotipering deurbreek waarvolgens homoseksuele mans nie tuis sou wees in 'n aggressiewe, harde sport soos rugby nie (berig in die Guardian 19 Desember 2009). Om die eie identiteit self te artikuleer is om tot outentieke bestaan te kom. Homoseksuele kontradiskoerse sal altyd teenstand ontlok, omdat dit weerstand teen diskursiewe heteronormatiwiteit bied. Dit is egter wel die moeite werd omdat die proses 'n 'oop sosiale ruimte' bied waarbinne nuwe identiteite geskep en uitgeleef kan word (Halperin 1995:67).

Die dekonstruksie van heteroseksistiese diskoerse kan dus op twee vlakke afspeel, naamlik op 'n teoretiese en 'n praktiese vlak. Op teoretiese vlak wys Habermas op die 'kognitiewe emansipatoriese belang' van sosiale bewusmaking (Van Aarde 2012:2). Diskoerse in die samelewing verander wanneer die openbare mening verskuif omdat mense bewus word van onreg. Ook op teoretiese vlak is die onderskeid tussen omgekeerde diskoerse en kontradiskoerse belangrik. Dit is 'n teoretiese saak wat ook in die praktyk tereg kan kom en 'n verskil kan maak aan die klein narratiewe, soos die verhaal van Thomas illustreer. In die praktyk funksioneer kontradiskoerse as radikaal (Moussa \& Scapp 1996:92). Hierdie kontra-identiteit gaan radikaal in teen die normatiewe, waar dit steeds blootgestel word aan diskoerse wat daardie stem van andersheid wil stilmaak. Ten spyte van hierdie ongemaklike posisie meen Foucault (1997:177) in sy werk 'Subjectivity and truth' dat elke subjek 'n morele verantwoordelikheid het, nie net teenoor hom- of haarself nie, maar ook aan ander, om die waarheid oor sigself te leer ken en te vertel. Indien mense hulleself definieer, word hulle die bron van kennis eerder as die een wat bestudeer word.

\section{Implikasies}

Indien aanvaar word dat die weg van kontradiskoers meer heilsaam sal wees vir homoseksuele mense as omgekeerde diskoerse, is die vraag wat die etiese implikasies van hierdie eie artikulasie van identiteit sal wees. Wat sal byvoorbeeld die rol van die kerk as instelling wees wanneer ' $n$ nuwe generasie self hulle identiteit en verhoudings definieer? Foucault (1985:10-11) benut wat Griekse en Romeinse outeurs 'n estetiese bestaan of die kuns van die lewe genoem het om oor die implikasies te besin. Hierdie 'lewenswyse' word gegrond op 'n onafhanklike regulering van die self wat plesier betref (seksualiteit ingesluit), en die individu neem self besluite oor moraliteit. Vir die ontwikkelingspsigoloog Lawrence Kohlberg (1973:630-646, 1981) is morele outonomie die hoogste en mees gesofistikeerde vlak van morele ontwikkeling. In die Grieks-Romeinse kultuur was selfdissipline ten opsigte van seksuele gedrag die sleutel tot geluk, wysheid en reinheid. Etiek is in antieke kulture verstaan as die 'relation between the individual and itself' (Halperin 1995:70) in plaas van 'n vooropgestelde norm vir openbare gedrag. Hierdie geïndividualiseerde, niekonformerende aard van die antieke Grieks-Romeinse kultuur staan teenoor die ontluikende Christelike tradisie wat universele morele kodes geskep het vir die regulering van seksualiteit (kyk Spargo 1999:24-25).

In die postmoderne tydsgees word moraliteit nie meer gesien as om te konformeer aan 'n gegewe stel reëls nie. Daar is ruimte vir die soeke na 'an aesthetics of existence' (Halperin 1995:68). Die vraag is of hedendaagse teologiese refleksie insigte te bied het vir so 'n soeke. Etiek gaan spesifiek oor die verhouding met die ander. Emmanuel Levinas (1969, 2003, 2011) skryf dit met 'n hoofletter: 'die Ander'. Die Self/ Eie (le Même in Frans) teenoor die Ander (l'Autre) verstaan hy as twee persone wat na mekaar kyk. Die Ander kan met 'n oogopslag uiterlik waargeneem word. Daardie persoon se identiteit, eie stem en unieke behoeftes kan egter nie uiterlik waargeneem word nie. Die kern van die persoon se andersheid noem Levinas die naaktheid van die Ander. Dit is slegs met die ontbloting van die Ander dat die Self aangeraak kan word en verander (kyk Peperzak1993:20). Deur die Ander bekom 'n mens kennis van buite die self (kyk Waldenfels 2002:68) en so verbreek die andersheid van die Ander die totalitêre (uitsluitende) verstaan van die eie werklikheid (Peperzak 1993:14-22). 'n Totalitêre werklikheid staan teenoor die oneindige, grenslose Ander. Die nuwe, die vreemde wat 'n mens se eie werklikheid binnedring, behoort nie geïntegreer word in, of gereduseer word tot die verstaan van die eie nie. Dit is juis kennis wat 'n mens noop om die verstaan van die eie in ontmoeting met die Ander te herevalueer (Waldenfels 2002:66-72).

Levinas (1969) se verstaan van die Ander kan beide horisontaal en vertikaal toegepas word. Hy verwys na die vertikale verhouding met die oneindige (infinite) Ander en hoe hierdie onbegryplike oneindige die totalitêre werklikheid van die Self (die mens) oorstyg (vgl. Waldenfels 2002). As die horisontale aspek toegepas word op die relasie met homoseksuele mense as die Ander, gaan dit daaroor dat die vreemde Ander as outentieke identiteit die totalitêre heteronormatiewe werklikheid van die Self oopbreek. So kan die Self die eie verstaan van dinge herevalueer en tot nuwe kennis kom, wat die Self transendeer. Levinas se werk beklemtoon die onreduseerbare waardigheid van die mens, die belangrikheid van vryheid en die verantwoordelikheid van die mens teenoor die Ander as ook 'n mens (Levinas \& Poller 2003:ix). 
In solidariteit gaan dit vir hom daarom dat nie net die waardigheid van die individuele Ander erken en beskerm word nie, maar ook die waardigheid van die mensdom as geheel. Dit onderstreep waardes soos intermenslike moraliteit, gemeenskap met ander en sosiale geregtigheid (Levinas \& Poller 2003:xviii). In sy werk Otherwise than being or beyond essence (Levinas \& Lingis 2011:xxvii),verwys Levinas na die Bybelse opdrag om die ander lief te hê soos jouself (Mark 12:31). Dit beteken nie om die Ander volgens die eie waardes te beoordeel nie, maar eerder om die persoon in sy of haar totale andersheid te aanvaar en selfloos die grens na die Ander oor te steek en eiebelang agter te laat.

Die teologiese perspektief op die kwessie van heteroseksisme en homofobie kan in verband gebring met Levinas se konsep van die Ander, en op hierdie grondslag kan 'n pastorale praktyk bedink word wat vir die kerk sowel as hedendaagse Christene, insluitende gelowiges wat tot seksuele minderhede behoort, tot voordeel wees.

Heteronormatiewe eksklusiwiteit funksioneer egter steeds op verskeie lae van die samelewing en kerk. Heteronormatiwiteit het te doen met die beoefening van mag ter wille van dominante groepe se belange. Hierdie magsuitoefening word ook op individuele a-sistemiese vlak voltrek. Teologies gesproke gaan mag met verantwoordelikheid gepaard. Die positiewe gebruik van mag is wanneer barmhartigheid aan swakkes betoon word (Loader 1975:350; vgl. Peperzak 1993:27). Mag hoef nie net negatief en onderdrukkend te wees nie, maar kan ook skeppend en helend, veral ten behoewe van die swakke, aangewend word.

Die vraag is wat die taak van teologie en kerk in hierdie konteks van onderdrukkende diskoerse sal wees wat die kerk self oor eeue help skep en onderhou het. In die geval van diskriminasie teen homoseksuele persone behoort kerk en teologie se aandeel ontbloot te word (kyk Dreyer 2006a:454). Die kerk is by uitstek die instelling wat magsmisbruik behoort teen te werk. Die fokus behoort te verskuif vanaf die sogenaamde 'immoraliteit' van 'n homoseksualiteit na die immoraliteit van 'n kerk en Christene wat ter wille van eie magsbelange skade aan ander veroorsaak.

Nie net behoort die kerk erns te maak met die omvang en implikasies van die onderdrukking van en haat teenoor seksuele minderhede nie, maar behoort ook 'n profetiese stem te laat hoor teen onreg, geweld en vooroordeel wat die direkte gevolg is van diskoerse wat getuig van homofobie. Kontradiskoerse behoort ook in die pastoraat wat die heling van gewonde mense ten doel het, geskep te word. Die narratiewe beradingsmodel bied ' $n$ goeie geleentheid om met behulp van verhale kontranarratiewe en kontradiskoerse te konstrueer. Deur middel van 'n proses van bewusmaking kan seksuele minderhede gehelp word om die magsmisbruik van die dominante kragte te identifiseer en die effek wat dit op hulle lewens en omstandighede het, te benoem. In die pastorale interaksie kan hulle vaardighede aanleer om 'n nuwe outentieke identiteit te konstrueer en uit te leef. Die nuwe identiteit sal dan gebaseer wees op eie waarhede en sal nie onderworpe wees aan die normaliserende en beperkende kragte en diskoerse nie. Verder is die taak van die pastoraat om die persone se egokragte sodanig op te bou en te versterk dat hulle in staat is om outentiek te lewe ten spyte van voortgesette diskriminasie en onderdrukking. Die doel is om te bly weerstand bied deur die uitlewing van die ander identiteit.

Benewens die begeleiding van seksuele minderhede en hulle naasbestaandes het die kerk ook die verantwoordelikheid om diskoerse in die kerk en samelewing wat getuig van homofobie, teen te werk sodat daar die Ander met die nodige respek en Christelike liefde aanvaar kan word vir wie hulle is. Die kerk kan dialoog fasiliteer sonder om afbreuk te doen aan die unieke individualiteit van die Ander. So kan kerke in ' $n$ multi-kulturele en diverse Suid-Afrika ' $n$ positiewe verskil maak aan die sosiale landskap wat bestaan uit 'n mengelmoes van minderheidsgroepe. So 'n diskoers kan selfs bydra om rasse-spanning in die samelewing te verlig. 'n Benadering van intergroep- verbintenisse (Pettigrew 1998) wat respekvol omgaan met die Ander, sal op meer terreine as net homoseksualiteit, heteronormatiwiteit en homofobie 'n bydrae kan lewer.

\section{Erkenning Mededingende belange}

Die outeurs verklaar dat hulle geen finansiële of persoonlike verbintenis het met enige party wat hulle nadelig in die skryf van hierdie artikel kon beïnvloed nie.

\section{Outeursbydrae}

Hierdie artikel is 'n verwerkte weergawe van aspekte van die MTh-verhandeling van M.l.R (Universiteit van Pretoria), met Y.D. (Universiteit van Pretoria) as promotor.

\section{Literatuurverwysings}

Allen, A., 2002, 'Power, subjectivity, and agency: between Arendt and Foucault', International Journal of Philosophical Studies 10(2), 131-149. http://dx.doi.org/ 10.1080/09672550210121432

Allport, G.W., 1958, The nature of prejudice, Addison-Wesley, Cambridge, MA.

BBC News, 1999, 'Bomb blast in gay clubland', viewed 21 January 2012, from http:// news.bbc.co.uk/2/hi/africa/507805.stm

Beeld.com., 2008, 'Gay orrelis wen saak', besigtig 28 Julie 2012, by http://www.beeld. com/Suid-Afrika/Nuus/Gay-orrelis-wen-saak-20100617

Beeld.com. 2011a, 'G'n legitimering vir gay student', viewed 26 May 2012, from http:// www.beeld.com/Suid-Afrika/Nuus/Gn-legitimering-vir-gay-student-20111129

Beeld.com. 2011b, 'Vasgevang in oerbeeld', besigtig 26 Mei 2012, by http://www. beeld.com/In-Diepte/Nuus/Vasgevang-in-oerbeeld-20111212

Berman, M., 1970, The politics of authenticity: radical individualism and the emergence of modern society, Allen \& Unwin, London.

Bevir, M., 1999, 'Foucault and critique: Deploying agency against autonomy', Political Theory 27(1), 65-84.

Brawley, R.L. (ed.), 1996, Biblical ethics and homosexuality: Listening to Scripture, Westminster John Knox Press, St. Louis, MS.

Brown, C.E., 2008, 'Racism in the gay community and homophobia in the black community: Negotiating the gay black male experience, Master of Science thesis in Sociology', Virginia Polytechnic Institut and State University.

Cantarella, E., [1988] 2002, Bisexuality in the ancient world, 2nd edn., transl. C.O. Cuilleanain, Yale University Press, New Haven, CT.

Constantine-Simms, D. (ed.), 2001, The greatest taboo: Homosexuality in black communities, Alyson, Los Angeles, CA.

Davidson, A.I., 1987, 'How to do the history of psychoanalysis: a reading of Freud's three essays on the theory of sexuality', Critical Enquiry 14, 252-277. 
Davidson, C., 2012, 'Everyday racism, everyday homophobia: A symposium on the intersections of race, gender, and sexuality', viewed 08 November 2012, from http:// intersections of race, gender, and sexuality', viewed 08 November 2012
hastac.org/blogs/cathy.../everyday-racism-everyday-homophobia

De Gruchy, J. \& Lewin, S., 2001, 'Ethics that exclude: the role of ethics committees in lesbian and gay health research in South Africa', American Journal of Public Health 91(6), 865-868.

Dias, R.M., Ayala, G., Bein, E., Henne, J. \& Marin, B.V., 2001, 'The impact of homophobia poverty, and racism on the mental health of gay and bisexual Latino men: Findings from 3 US cities', American Journal of Public Health 91(6), 297-932.

Dreyer, Y. 2005, 'Sexuality and shifting paradigms: Setting the scene', HTS Teologiese Studies/Theological Studies 61(3), 729-751. http://dx.doi.org/10.4102/hts.v61i3.471

Dreyer, Y. 2006a, 'Prejudice, homophobia and the Christian faith community', Verbum et Ecclesia 27(1), 155-173. http://dx.doi.org/10.4102/ve.v27i1.137

Dreyer, Y., 2006b, 'Heteronormatiwiteit, homofobie en homoseksualiteit: 'n Roetekaart vir'n inklusiewe kerk', HTS Teologiese Studies/Theological Studies 62(2), 445-471. http://dx.doi.org/10.4102/hts.v62i2.375

Dreyer, Y. 2007, 'Hegemony and the internalisation of homophobia' HTS Teologiese Studies/Theological Studies 63(1), 1-18. http://dx.doi.org/10.4102/hts.v63i1.197

Farlam, P., 1997, 'Liberation through the law? The constitution and the church', in P. Germond \& S. de Gruchy (eds.), Aliens in the household of God, pp. 132-145, David Phillip, Cape Town.

Foucault, M., [1969] 1982, The archaeology of knowledge \& the discourse on language, transl. A. Sheridan, Pantheon, NY.

Foucault, M., 1972, The archaeology of knowledge, transl. A. Sheridan, Tavistock, London.

Foucault, M., 1978, History of sexuality. Volume I: An introduction, transl. R. Hurley, Random House, NY.

Foucault, M., 1980, 'Power/knowledge', in C. Gordon (ed.), Selected interviews and other writings 1972-1977, pp. 109-133, Pantheon Books, New York, NY.

Foucault, M., 1985, The use of pleasure, transl. R. Hurley, Random House, New York, NY. (The history of sexuality, vol. 2).

Foucault, M., 1997, 'Subjectivity and truth', in S. Lotringer \& L. Hogtroth (eds.), The politics of truth, pp. 171-198, Semiotext(e), New York, NY.

Foucault, M., [1982] 2001a, 'Truth and power', in J.D. Faubion (ed.), Power: The essential works of Foucault 1954-1984, pp. 111-133, transl. R. Hurley, New Press, New York, NY.

Foucault, M., [1982] 2001b, 'The subject and power', in J.D. Faubion (ed.), Power: The essential works of Foucault 1954-1984, pp. 326-348, transl. R. Hurley, New Press, New York, NY.

Fourie, H., 2011, 'Gay man moet R1.4 m kry', Beeld, 09 Desember, besigtig 28 Julie 2012 by http://www.beeld.com/Suid-Afrika/Nuus/Gay-man-moet-R14-m-kry-20111209

Freedman, J. \& Combs, G., 1996, Narrative therapy: The social construction of preferred realities, Norton, New York, NY.

The Guardian, 2009, 'Wales rugby legend Gareth Thomas comes out as gay', viewed 31 July 2012, from http://www.theguardian.com/sport/2009/dec/19/gareththomas-gay\#box

Gurney, C.M., 1999, 'Pride and prejudice: Discourses of normalisation in public and private accounts of home ownership', Housing Studies 14(2), 163-183.

Halperin, D.M., 1989, 'Is there a history of sexuality?', History and Theory 28(3), 257-274, viewed 11 July 2012, from http://0-www.jstor.org.innopac.up.ac.za/stable/2505179

Halperin, D.M., 1990, One hundred years of homosexuality and other essays on Greek love, Routledge, London.

Halperin, D.M., 1995, Saint Foucault: Towards a gay hagiography, Oxford University Press, New York, NY.

Herek, G.M., 1986, 'On heterosexual masculinity: Some psychical consequences of the social construction of gender and sexuality', American Behavioral Scientist 29, 563-577.

Herek, G.M., 1988, 'Heterosexuals' attitudes toward lesbians and gay men: Correlates and gender differences', The Journal of Sex Research 25(4), 451-477.

Herek, G.M., 1992, 'The social context of hate crimes: Notes on cultural heterosexism', in G.M. Herek \& K.T. Berril (eds.), Hate crimes: confronting violence against lesbians and gay men, pp. 89-104, Sage, London.

Herek, G.M., 2004, 'Beyond homophobia: Thinking about sexual prejudice and stigma in the twenty-first century', Sexuality Research \& Social Policy 1(2), 6-24, viewed in the twenty-first century', Sexuality Research \& Social Policy 1(2), 6-24, viewed
03 Augustus 2012, from http://0-www.springerlink.com.innopac.up.ac.za/ 03 Augustus 2012, from http://0-ww
content/e621m03x780l3047/fulltext.pdf

Herek, G.M., 2007, Confronting sexual sigma and prejudice: Theory and practice, viewed 06 Augustus 2012, from http://0-psychology.ucdavis.edu.innopac.up.ac. za/rainbow/html/Herek_2007_JSI_preprint.pdf

Herek, G.M. \& Gilles, J.R. \& Cogan, J.C., 2009, Internalized stigma among sexual minority adults: Insights from a social psychological perspective, viewed 06 Augustus 2012 from http://0-psychology.ucdavis.edu.innopac.up.ac.za/RAINBOW/html/Herek etal_2009_JCP_preprint.pdf

Hooks, B., 1989, Talking back, South End, Cambridge, MA.

Hooks, B., 2001, 'Homophobia in black communities', in D. Constantine-Simms (ed.), The greatest taboo: Homosexuality in black communities, pp. 67-73, Alyson, Los The greatest
Angeles, CA.

Kohlberg, L., 1973, 'The claim to moral adequacy of a highest stage of moral judgment', Journal of Philosophy 70(18), 630-646.

Kohlberg, L., 1981, Essays on moral development: The philosophy of moral development Harper \& Row, San Francisco, CA.

Krause, W., 2007, 'The narrative negotiation of identity and belonging', in M.G.W. Bamberg (ed.), Narrative: State of the art, pp. 123-132, John Benjamins, Amsterdam.
Langelier, K.M., 2001, 'You're marked': Breast cancer, tattoo, and the narrative performance of identity', in J. Brockmeier \& D. Carbaugh (eds.), Narrative and performance of identity', in J. Brockmeier \& D. Carbaugh (eds.), Narrative and
identity: Studies in autobiography, self and culture, pp. 145-184, John Benjamins, identity: Studies

Levinas, E., 1969, Totality and infinity: An essay on exteriority, transl. A. Lingis, Duquesne University Press, Pittsburg, PA.

Levinas, E. \& Poller, N. (eds.), 2003, Humanism of the other, University of Illinois Press, Chicago, IL.

Levinas, E. \& Lingis, A. (eds.), 2011. Otherwise than being or beyond essence, 9th edn. Duquesne University Press, Pittsburgh, PA, viewed 03 August 2013, from http:// chungsoolee.com/files/OB_wholebook_word.pdf

Loader, J.A., 1975, 'Aspekte van menslike mag in die Ou Testament', ThD-proefskrif, Afdeling Ou Testamentiese Wetenskap, Rijksuniversiteit Groningen.

Martin, D.B., [1996] 2013, 'Arsenokoités and malakos: Meanings and consequences', reproduced from R.L. Brawley (ed.), 1996, Biblical ethics \& homosexuality: Listening to Scripture, Westminster John Knox Press, St. Louis, MS, viewed 22 March 2013, to Scripture, Westminster John Knox Press, St. Loulis, MS, viewed
from http://www.clgs.org/arsenokoités-and-malakos-meanings

McHoul, A. \& Grace, W.,1993, A Foucault primer: Discourse, power and the subject, City Press, New York, NY.

McWhorter, L., 1999, Bodies and pleasures: Foucault and the politics of sexual normalization, Indiana University Press, Bloomington, IN.

Miller, J.A. \& Miller, R., 1987, Jeremy Bentham's panoptic device, MIT Press, Cambridge, MA.

Moussa, M. \& Scapp, R., 1996, 'The practical theorizing of Michel Foucault: politics and counter-discourse', Cultural Critique 33, 87-112, viewed 25 July 2012, from and counter-discourse', Cultural Critique

Nederduitsch Hervormde Kerk van Afrika (NHKA), 2010, Besluitebundel van die 69ste Algemene Kerkvergadering, besigtig 19 Junie 2011, by http://www.nhk.co.za/
$\mathrm{cms} /$ images/stories/Kerklike_dokumente/Besluitebundel/69ste_AKV/10_ cms/images/stories/Kerklike_dokument

Nieman, A. 2010, 'Churches and social development in South Africa', in I. Swart, H. Rocher, S. Green \& J. Erasmus (eds.), Religion and social development in postapartheid South Africa, n.p., Sun Press, Stellenbosch.

News24, 2012, 'Gay pageant winner murdered', viewed 25 June 2012, from http:// www.news24.com/SouthAfrica/News/Gay-pageant-winner-beheaded-20120613

News24, 2013, 'Academy claims to cure homosexuality', viewed 25 January 2013 from http://www.news24.com/SouthAfrica/News/Academy-claims-to-curehomosexuality-20130113

NGK Algemene Sinode, 2007, Bes/uiteregister, besigtig 22 Augustus 2012, by http://www. ngkerk.org.za/documents/Besluiteregsiter\%202007\%20(F)\%20p193-p223.pdf

Otto, P.B., 2003, 'A participatory inquiry into cultural and religious discourses that either silence or promote gay voices', PhD dissertation, Department of Psychology, University of Pretoria.

Peperzak, A. (ed.), 1993, To the other: An introduction to the philosophy of Emmanuel Levinas, Purdue University Press, West Lafayette, IN.

Pettigrew, T.F., 1998, 'Intergroup contact theory', Annual Review of Psychology 49, 65-85.

Raja, S. \& Stokes, J.P., 1998, 'Assessing attitudes toward lesbian and gay men: The modern homophobia scale', Journal of Gay, Lesbian, and Bisexual Identity 3(2), 113-134.

Reddy, V., 2001. 'Institutionalizing sexuality: Theorizing queer in post-apartheid South Africa', in D. Constantine-Simms (ed.), The greatest taboo: Homosexuality in black communities, pp. 163-184, Alyson, Los Angeles, CA.

Richlin, A., 1997, 'Foucault's History of sexuality: A useful theory for women?, in D.H.J. Larmour, P.A. Miller \& C. Platter (eds.), Rethinking sexuality: Foucault and classical antiquity, pp. 138-170, Princeton University Press, Princeton, NJ.

Rizzo, D., 2006, 'Public spheres and gay politics since the Second World War', in R. Aldrich (ed.), Gay life and culture: a world history, pp. 197-221, Universe, New York, NY.

Robinson, K.H. \& Ferfolja, T., 2002, 'A reflection of resistance', Journal of Gay \& Lesbian Social Services 14(2), 55-64.

Silverstein, C., 2008, The implications of removing homosexuality from the DSM as a mental disorder, viewed 15 July 2012, from http://0-www.springerlink.com. innopac.up.ac.za/content/m10532251319q649/fulltext.pdf

Spargo, T., 1999, Foucault and queer theory, Cox \& Wyman, Reading, MA.

The Conversation, 2012, From homophobia to homophilia: The future face of medicine, viewed 15 July 2012, from http://theconversation.edu.au/from-homophobia-tohomophilia-the-future-face-of-medicine-5899

Tomsen, S., 2001, 'Hate crimes and masculine offending', Gay and Lesbian Law Journal 10, 26-42.

Van Aarde, A.G., 2012, 'Verset teen mag: Die pelgrim se reis in drie "Sondergut" gelykenisse in Lukas 15 en 16', HTS Teologiese Studies/Theological Studies 68(1), gelykenisse in Lukas 15 en 16 ', HTS Teologiese S
$1-12$. http://dx.doi.org/10.4102/hts.v68i1.1032

Van Eck, E., 2007, 'Die huwelik in die eerste-eeuse Mediterreense wêreld (I): Vroue in'n man se wêreld', HTS Teologiese Studies/Theological Studies 63(1), 81-101. http://dx.doi.org/10.4102/hts.v63i1.204

Van Niekerk, G.J. \& Wildenboer, L., 2009, The origins of South African law, UNISA Press, Pretoria.

Waldenfels, B., 2002, 'Levinas and the face of the other', in S. Critchley \& R. Bernasconi (eds.), The Cambridge companion to Levinas, pp. 63-81, Cambridge University Press, Cambridge, MA.

Wells, H. \& Polders, L., 2006, 'Anti-gay hate crimes in South Africa: Prevalence, reporting practices, and experiences of the police', Agenda: Empowering Women for Gender Equity 20(67), 20-28. http://dx.doi.org/10.1080/10130950.2006.9674694 